OPEN ACCESS

Edited by:

Ralf J. Ludwig

Universität zu Lübeck, Germany

Reviewed by:

Hiroshi Koga,

Department of Dermatology, Kurume University School of Medicine, Japan

Günther F.L. Hofbauer,

Universität Zürich, Switzerland

${ }^{*}$ Correspondence:

Teruki Dainichi

dainichi@kuhp.kyoto-u.ac.jp

Specialty section:

This article was submitted to

Dermatology,

a section of the journal

Frontiers in Medicine

Received: 28 May 2018

Accepted: 20 July 2018

Published: 08 August 2018

Citation:

Dainichi T and Kabashima K (2018) Interaction of Psoriasis and Bullous

Diseases. Front. Med. 5:222.

doi: 10.3389/fmed.2018.00222

\section{Interaction of Psoriasis and Bullous Diseases}

\author{
Teruki Dainichi ${ }^{1 *}$ and Kenji Kabashima ${ }^{1,2}$ \\ ${ }^{1}$ Department of Dermatology, Kyoto University Graduate School of Medicine, Kyoto, Japan, ${ }^{2}$ Singapore Immunology \\ Network and Institute of Medical Biology, Agency for Science, Technology and Research (A*STAR), Singapore, Singapore
}

Patients with psoriasis are frequently complicated with autoimmune bullous diseases, especially, pemphigoid diseases. It has been known that one-third cases of anti-laminin gamma1 pemphigoid, formerly anti-p200 pemphigoid, are associated with psoriasis whereas bullous pemphigoid is the most frequently associated bullous disease in psoriasis cases regardless of the lack of detectable levels of the accompanying antilaminin gamma1 autoantibodies. Despite several suggestions, however, the definitive reason of the striking association of psoriasis and these autoimmune bullous diseases remains elusive. In this review, we look over the epidemiological evidence of the association of psoriasis and autoimmune bullous diseases and the information of genetic susceptibilities of each disease, and discuss the possible mechanisms of their complication with reference to the recent understandings of each pathogenesis.

Keywords: autoimmunity, Th2, Th17, psoriasis, pemphigoid, laminin, MMP, senescence

\section{INTRODUCTION}

Autoimmune bullous diseases, as well as psoriasis, are skin disorders affecting the epidermis. In both diseases, immune reactions target the epidermis, and induce the development of the skin lesions following the failures in epithelial cell contacts or the defects in epithelial cell proliferation and differentiation. There is remarkable progress in the understandings of their pathogenesis in these decades, respectively. Nevertheless, (1) what triggers the pathogenic immune reactions, (2) which cells by which molecules respond to the internal or external changes and direct the subsequent immune reactions, and (3) which step is critical for the decision of the immune type, have not yet been fully elucidated.

Physicians and dermatologists have long time been aware that psoriasis patients are frequently complicated with autoimmune bullous diseases. Indeed, epidemiological evidence indicates that the incidence of some pemphigoid diseases in psoriasis patients is significantly higher than that in the control individuals without psoriasis. Moreover, recent investigations have suggested that there are in part similarities and shared players in their pathogenesis.

In this review, first we look over the epidemiological evidence of the association of psoriasis and autoimmune bullous diseases. Second, we compare their genetic susceptibilities. And third, we discuss the possible mechanisms of their association with reference to the current understandings on each pathogenesis. 


\section{EPIDEMIOLOGICAL EVIDENCE}

\section{Psoriasis and Pemphigus}

Most reported cases of pemphigus developed in psoriasis patients were pemphigus foliaceus including pemphigus erythematosus. A case series of 145 patients with concomitant psoriasis and autoimmune blistering diseases from Japan reported that all four (2.8\%) pemphigus cases with psoriasis were pemphigus foliaceus (124). The first case-control study of 51,800 psoriasis patients from Taiwan demonstrated the significantly higher prevalence rate of pemphigus in the patients than that in the control subjects (odds ratio (OR), 41.8; 95\% confidence interval (CI), 12.4-140.9; $P<0.0001)$ (125).

There is another study evaluating their association in an inverse direction: a case-control study of 1985 pemphigus patients from Israel demonstrated that the prevalence rate of psoriasis in pemphigus patients was also higher than that in the controls (OR, 2.84; 95\% CI, 2.09-3.85, $P<0.001$ ) (126).

\section{Psoriasis and Pemphigoid Diseases Including Epidermolysis Bullosa Acquisita}

Complication of psoriasis cases with pemphigoid diseases are much more commonly experienced than those with pemphigus whereas the number of the report of the psoriasis cases with pemphigoid is only about three times as many as those with pemphigus (Figure 1). Indeed, in the case series of 145 patients with psoriasis and autoimmune blistering diseases from Japan, almost all the cases are complicated with bullous pemphigoid (63\%), anti-laminin $\gamma 1$ pemphigoid (formerly antip200 pemphigoid) (37\%), or their combination (8\%) (Figure 2). Psoriasis including pustular psoriasis precedes the development of pemphigoid in most cases. Of note, 111 (78.7\%) cases had no history of any phototherapies in this case series (124).
The case-control study of 51,800 psoriasis patients from Taiwan also demonstrated the higher prevalence rate of pemphigoid in the patients than that in the control subjects (OR, 14.8; 95\% CI, 5.00-43.50, $P<0.0001$ ) (125).

Inversely, early case-controlled study has shown that 7 out of $62(11 \%)$ pemphigoid cases are complicated with psoriasis and the prevalence was significantly higher than expected in the controls $(P<0.01)(40)$. Following studies also confirmed that psoriasis cases are significantly associated with bullous pemphigoid: A study of 3,485 bullous pemphigoid cases from Taiwan (OR 2.02; 95\% CI 1.54-2.66, $P<0.003$ ) (127), and another of 287 bullous pemphigoid cases from Israel (OR 4.39; 95\% CI 2.17-8.92, $P<0.0001$ ) (128), respectively.

Anti-laminin $\gamma 1$ pemphigoid is originally reported as pemphigoid developed in psoriasis patients with circulating autoantibodies against unknown autoantigen. Around one-third of the following cases have also been associated with psoriasis (129).

There are only a few reported cases of psoriasis associated with other pemphigoid diseases. The case series of 145 patients with psoriasis and autoimmune blistering diseases from Japan included three cases with linear IgA bullous dermatosis and two cases with epidermolysis bullosa acquisita (124). There are few independent reports of a case with epidermolysis bullosa acquisita $(51,112)$, or with anti-laminin 332 mucous membrane pemphigoid (109).

\section{Psoriasis and Other Blistering Diseases}

Intriguingly, as far as we looked up, there is no reported case of psoriasis in any type of epidermolysis bullosa: simplex, junctional, or dystrophic type, except for one case report of the dystrophic type without confirmation by DNA sequencing analysis (116). There are seven reports of a case with psoriasis in Hailey-Hailey disease since the first reported case (117).

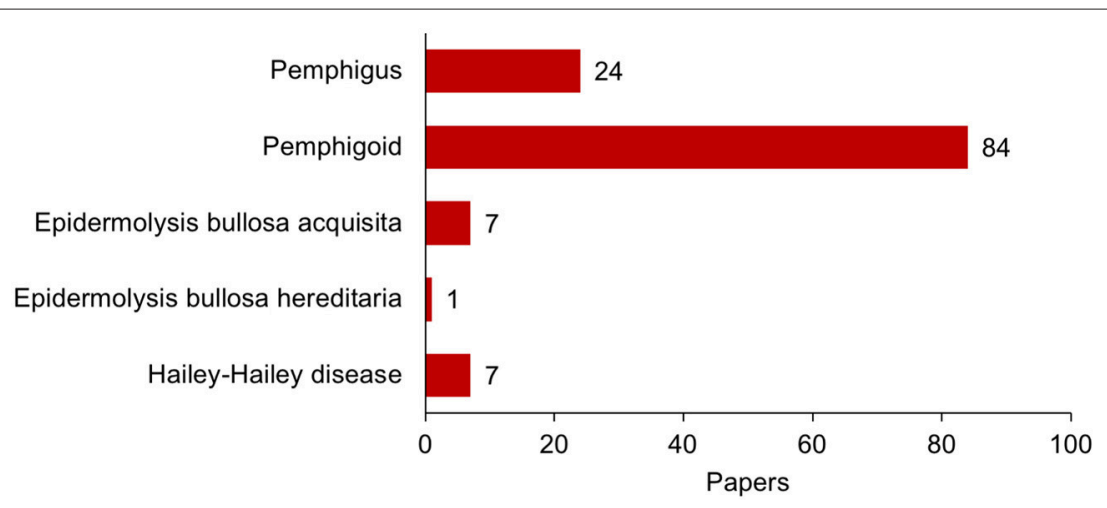

FIGURE 1 | Publication of the report of cases with association of psoriasis and bullous diseases until the end of 2017. All the publications were searched in PubMed database, and case reports and case series were selected manually with exclusion of redundancy. Cases with coexistence of two or more autoimmune blistering diseases were counted in each category: (psoriasis[tiab] AND pemphigoid[tiab]) for pemphigoid diseases; (psoriasis[tiab] AND pemphigus[tiab] NOT pemphigoid[tiab]) for pemphigus; psoriasis[tiab] AND (epidermolysis bullosa acquisita[tiab]) for epidermolysis bullosa acquisita; psoriasis AND (epidermolysis bullosa hereditaria OR epidermolysis bullosa simplex OR junctional epidermolysis bullosa OR dystrophic epidermolysis bullosa OR kindler's syndrome OR kindler syndrome) for epidermolysis bullosa hereditaria; psoriasis[tiab] AND (hailey-hailey OR familial pemphigus OR familial benign chronic pemphigus) for Hailey-Hailey disease. References are as follows. Pemphigus (24): 1990 or earlier (5) (1-5); 1991-2000 (5) (6-10); 2001-2010 (6) (11-16); 2011 or later (8) (17-25). Pemphigoid (84): 1980 or earlier (7) (26-32); 1981-1990 (16) (3, 33-47); 1991-2000 (10) (48-57); 2001-2010 (21) (58-78); 2011 or later (30) (79-109). Epidermolysis bullosa acquisita (7) (51, 110-115). Epidermolysis bullosa hereditaria (1) (116). Hailey-Hailey disease (7) (117-123). 


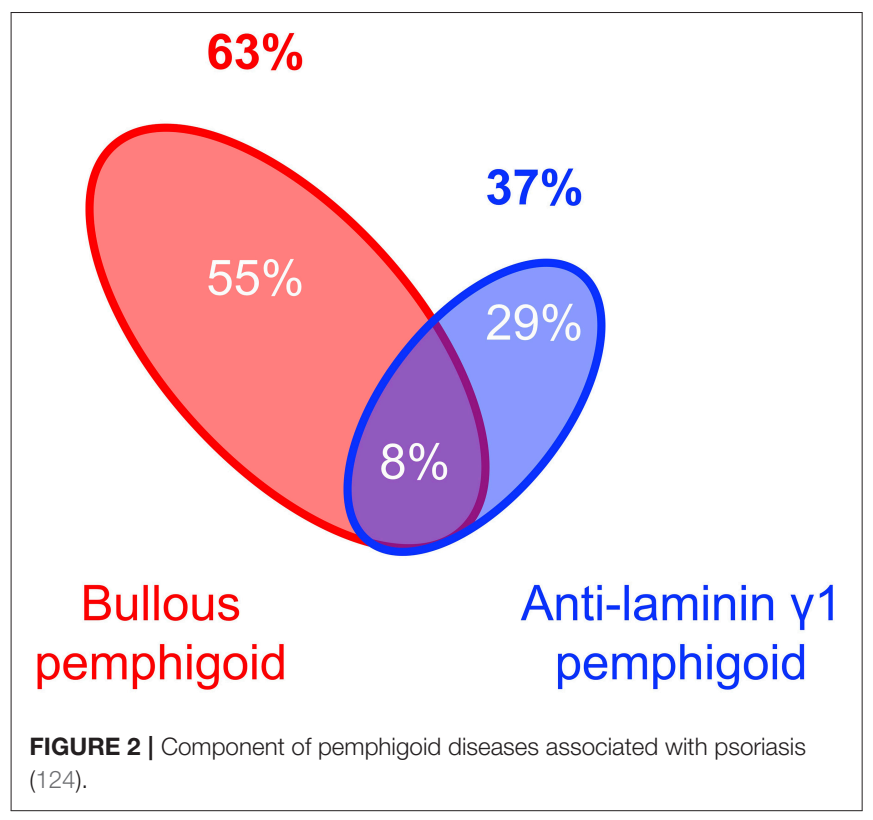

\section{SUSCEPTIBILITIES OF PSORIASIS AND BULLOUS DISEASES}

\section{HLA}

No shared susceptibility human leukocyte antigen (HLA) alleles have been reported between psoriasis and bullous diseases that can be associated with psoriasis: HLA-Cw*0602 allele has been identified in psoriasis susceptibility 1 (PSORS1), a major psoriasis susceptibility locus (130). On the other hand, HLA-DRB1 alleles, such as $\mathrm{DRB} 1^{\star} 1401, \mathrm{DRB} 1^{\star} 0402$, and $\mathrm{DRB} 1^{\star} 08$ alleles are associated with pemphigus vulgaris (131). HLA-DQB1*0301 allele has been identified as a susceptibility gene for bullous pemphigoid. Epidermolysis bullosa acquisita is associated with $\mathrm{DRB}^{*}$ 15:03 allele (132).

\section{Other Susceptibility Genes}

Studies for single nucleotide polymorphisms have been defined several psoriasis susceptibility genes $(130,133)$ (Table 1) whereas it has been challenging to identify the susceptibility genes of pemphigus or pemphigoid diseases and there is much less information about their susceptibility genes. As for two major bullous diseases that can be associated with psoriasis, following genes are suggested to be associated with the disease susceptibility:, IL1B (135), CD16 (136), ATP8 (137), and CYP2D6 (138) in bullous pemphigoid; and CD40L, CD40, BLYS (139), CTLA4 (140), and CD59 (141) in pemphigus foliaceus. However, they are not included in the major psoriasis susceptibility genes except for the risk loci at $I L 1 B$ in late onset psoriasis (142). Susceptible SNPs in mucous membrane pemphigoid were recently reported (143) whereas mucous membrane pemphigoid rarely accompanied with psoriasis.

\section{Transcriptomic Studies}

Whereas transcriptomic analyses are preferentially demonstrated to investigate the pathogenesis of psoriasis, it is not in the case of autoimmune bullous diseases. The increased expression levels of CD1D (4.0) and LILRB2 (4.7) were reported in pemphigus foliaceus (144), neither of them were included in the upregulated genes in psoriasis lesions (134) (Table 2).

Consequently, these results suggest that the complication of psoriasis with bullous pemphigoid or pemphigus foliaceus are not attributed to the shared susceptibility. Therefore, it would be more reasonable to consider that the epigenetic events in psoriasis lesions give rise to the increased rate of the complication with autoimmune bullous diseases.

\section{POTENTIAL MECHANISMS OF THE ASSOCIATION OF PSORIASIS AND PEMPHIGOID DISEASES}

\section{Local Inflammation}

Psoriasis plaques are the frequently affected sites for the blister formation of associated autoimmune bullous diseases, such as bullous pemphigoid (58), anti-laminin $\gamma 1$ pemphigoid (49), and pemphigus foliaceus (7). It would be reasonable to consider that epigenetic changes altered by psoriasis lesion may trigger or accelerate autoreactive response to specific antigens resulting in autoantibody production, blistering formation, and further positive loop of organ-specific autoimmunity (145). Whereas detailed speculations in this context are described below, it is of not that local inflammation exacerbates cutaneous manifestations in a murine autoimmune pemphigus model (146), suggesting effective recruitment of autoantibodies into psoriasis lesions and further autoimmune loop.

\section{Th17}

There are much more psoriasis cases complicated with bullous pemphigoid than those with pemphigus. We have demonstrated that the percentages of interleukin (IL)-17+ cells in CD4+ cells in the lesional skin from bullous pemphigoid are significantly higher than those in the lesional skin from pemphigus foliaceus, and that the serum levels of IL-17 in patients with bullous pemphigoid is higher than those in healthy controls (147). Although IL-17 from $\mathrm{T}$ helper type 17 (Th17) cells have an essential role in pathogenesis of psoriasis, it does not explain the common order of the disease development: bullous pemphigoid following psoriasis despite the existence of a rare, inverse case: psoriasis following bullous pemphigoid (77). However, one may speculate that pathological events around the epidermis shared between psoriasis and bullous pemphigoid is related to the activation of Th17 in these diseases, and incidental switch of the immune response from Th1 to Th2 induce the production of the IgG autoantibodies resulting the complication of psoriasis with bullous pemphigoid (77) (Figure 3). Because, animal studies have demonstrated that single helper $\mathrm{T}$ cell clone specific for desmoglein 3 is sufficient to recapitulate autoimmune blister formation whereas the Th17-deviated $\mathrm{T}$ cell clone specific for desmoglein 3 induces 
TABLE 1 | SNPs in psoriasis and the related bullous diseases (130, 133).

\begin{tabular}{lll}
\hline Disease & Category & Symbols \\
\hline Psoriasis & HLA & HLA-C*12:03, HLA-B, HLA-A, HLA-DQA1 \\
& MHC class-l processing & ERAP1 \\
& NF-KB signaling & TNIP1, NFKBIA, CARD14 \\
& IFN signaling & IL28RA, TYK2 \\
& T-cell regulation & RUNX3, IL13, TAGAP, ETS1, MBD2, PTPN22 \\
& Antiviral signaling & IFIH1, DDX58, RNF114 \\
& IL-23/IL-17 axis & TNFAIP3, IL23R, IL12B, TRAF3IP2, IL23A, STAT3 \\
IL2 & IL4, IL13 \\
Bullous pemphigoid & Late cornified envelope & LCE3B, LCE3C, LCE3D \\
multicolumn1IPemphigus foliaceus & Ubiquitin pathway & CDKAL1
\end{tabular}

TABLE 2 | Top 25 upregulated genes in the psoriasis lesions relative to the non-lesional skin (134).

\begin{tabular}{|c|c|c|c|}
\hline \# & Symbol & Description & Fold change \\
\hline 1 & SERPINB4 & serpin peptidase inhibitor, clade B (ovalbumin), member 4 & 661 \\
\hline 2 & S100A12 & S100 calcium binding protein A12 & 328 \\
\hline 4 & S100A7A & S100 calcium binding protein A7A & 260 \\
\hline 5 & SPRR2C & small proline-rich protein $2 \mathrm{C}$ (pseudogene) & 167 \\
\hline 8 & P/3 & peptidase inhibitor 3 , skin-derived & 80 \\
\hline 9 & IL8 & interleukin 8 & 66 \\
\hline 10 & TMPRSS11D & transmembrane protease, serine 11D & 63 \\
\hline 11 & SERPINB3 & serpin peptidase inhibitor, clade B (ovalbumin), member 3 & 62 \\
\hline 12 & S100A9 & S100 calcium binding protein A9 & 60 \\
\hline 16 & $R H C G$ & Rh family, C glycoprotein & 52 \\
\hline 17 & IGFL1 & IGF-like family member 1 & 48 \\
\hline 18 & KYNU & kynureninase (L-kynurenine hydrolase) & 48 \\
\hline 19 & IL1F9 & interleukin 1 family, member 9 & 43 \\
\hline 20 & $K L K 6$ & kallikrein-related peptidase 6 & 43 \\
\hline 21 & LTF & lactotransferrin & 36 \\
\hline 22 & CCL2O & chemokine (C-C motif) ligand 20 & 35 \\
\hline 23 & C10orf99 & chromosome 10 open reading frame 99 & 34 \\
\hline 24 & HPSE & heparanase & 33 \\
\hline 25 & $A D A M D E C 1$ & ADAM-like, decysin 1 & 33 \\
\hline
\end{tabular}

psoriasiform dermatitis $(148,149)$. Occasional production of autoantibodies against BP180 and desmogleins in lichen planus cases has been reported regardless of accompanying blister formation, probably because of the consequence of interface dermatitis, suggesting Th1/Th2 dichotomy among lichen planus vs. pemphigus or pemphigoid diseases (150). In psoriasis, however, production of neither autoantibodies against BP180 nor desmogleins, but $\alpha 6$ integrin (151), in psoriasis has been reported without complication with blistering diseases. It is therefore unlikely that psoriasis and bullous pemphigoid or pemphigus diseases are sharing their primary effector memory $\mathrm{T}$ cells. 


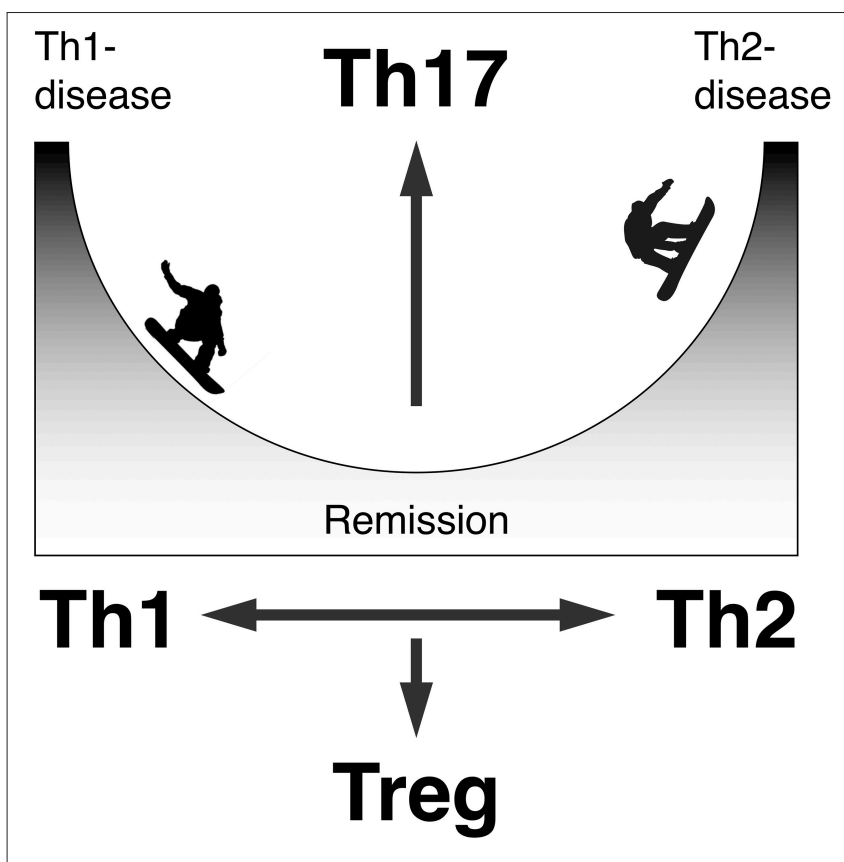

FIGURE 3 | A mechanistic model to produce autoantibodies in psoriasis. Can switch from the Th1/Th17-dominant to Th2/Th17-dominant state be involved?.

\section{Neutrophils and MMP}

Keratinocytes in both psoriasis and bullous pemphigoid produce neutrophil chemoattractants, such as IL-8, and infiltration of neutrophil is a common histologic feature in these diseases $(130,131)$. Consequently, neutrophils release a series of metalloproteases, and it might be related to the substantial degradation of matrix proteins and the subsequent exposure of the antigenic epitopes from matrix autoantigens composing the dermal-epidermal junction. Specifically, a disintegrin and metalloprotease (ADAM) 9, ADAM10, and ADAM17/ tumor necrosis factor-alpha converting enzyme (TACE) degrade BP180/type XVII collagen (152), which is a major autoantigen in bullous pemphigoid while matrix metalloprotease (MMP) 2, 7, 8, $12,14,15$, and 19 degrades laminins (153), of which trimers are targeted in anti-laminin $\gamma 1$ pemphigoid (154) and anti-laminin 332 mucous membrane pemphigoid (155).

\section{Laminins}

One may be tempted by the following idea: very high prevalence of psoriasis in anti-laminin $\gamma 1$ pemphigoid can be explained by a positive loop of laminin degradation in psoriasis (129). In psoriasis, as well as in trauma or staphylococcal

\section{REFERENCES}

1. Leoni A. [Pemphigus foliaceus during the course of psoriasis]. Minerva Dermatol. (1952) 27:238-40.

2. Chowaniec O, Blichowska T. [Case of generalized pustular psoriasis caused by corticosteroid treatment of simple psoriasis and pemphigus]. Przegl Dermatol. (1979) 66:541-4. infections, degradation of laminin is accelerated through the increased expression levels of $\alpha 5 \beta 1$ integrin, fibronectin, and plasminogen activators (156). The laminin degradation is also stimulated by MMP9 released from neutrophils. Furthermore, laminin fragments stimulate the MMP9 expression. This laminin degradation loop may be contributed to decrease the threshold of spontaneous production of autoantibodies against laminin $\gamma 1$ in the development of anti-laminin $\gamma 1$ pemphigoid in psoriasis patients.

\section{Senescence}

The median age of the development of bullous pemphigoid is around 80 years of age. Cell cycle and turnover of the epidermal keratinocytes are extremely accelerated in psoriasis whereas keratinocytes in psoriasis are not immortalized like carcinoma cells. Therefore, it is a plausible idea that the extracellular matrix in psoriatic skin simulates the senescent extracellular matrix and contribute to the development of bullous pemphigoid if the development of bullous pemphigoid is triggered by the senescence of the extracellular matrix produced by senescent keratinocytes. The shortened telomere lengths in psoriasis have not yet determined in keratinocytes or dermal fibroblasts, but in lymphocytes (157). In terms of senescence, type XVII collagen (BP180) changes its distribution (158) and the protein amount due to proteolysis (159) by aging. Despite several suggestions, however, the definitive reason of the predilection of bullous pemphigoid in an extremely old age remains to be elucidated.

\section{CONCLUDING REMARKS}

Epidemiological studies have confirmed that psoriasis is highly complicated by the subsequent development of autoimmune bullous diseases. The order of the disease development and the lack of shared susceptibility genes ask whether epigenetic events and molecular circumstances in psoriasis lesions raise the susceptibility to the organ-specific autoimmunity in the skin. The high prevalence of bullous pemphigoid and anti-laminin $\gamma 1$ pemphigoid in patients with psoriasis promotes following investigations on the pathogenesis of each disease, especially about their unique types of immune responses, as well as the involvement of the degradation and senescence of extracellular proteins around the dermalepidermal junctions.

\section{AUTHOR CONTRIBUTIONS}

All authors listed have made a substantial, direct and intellectual contribution to the work, and approved it for publication. 
5. Yokoo M, Oka D, Ueki H. Coexistence of psoriasis vulgaris and pemphigus foliaceus. Dermatologica (1989) 179:222-3. doi: 10.1159/000248369

6. Fryer EJ, Lebwohl M. Pemphigus vulgaris after initiation of psoralen and UVA therapy for psoriasis. J Am Acad Dermatol. (1994) 30:651-3. doi: 10.1016/S0190-9622(09)80116-3

7. Lee CW, Ro YS. Pemphigus developed on preexisting dermatoses. $J$ Dermatol. (1994) 21:213-5. doi: 10.1111/j.1346-8138.1994.tb01724.x

8. Perez GL, Agger WA, Abellera RM, Dahlberg P. Pemphigus foliaceus coexisting with IgA nephropathy in a patient with psoriasis vulgaris. Int J Dermatol. (1995) 34:794-6. doi: 10.1111/j.1365-4362.1995.tb04400.x

9. Panzarella K, Camisa C. Coexistence of superficial pemphigus and psoriasis. Cutis (1996) 57:414-8.

10. Morita E, Amagai M, Tanaka T, Horiuchi K, Yamamoto S. A case of herpetiform pemphigus coexisting with psoriasis vulgaris. $\mathrm{Br} J$ Dermatol. (1999) 141:754-5. doi: 10.1046/j.1365-2133.1999.03129.x

11. Stavropoulos PG, Kostakis PG, Papakonstantinou AM, Panagiotopoulos A, Petridis AD. Coexistence of psoriasis and pemphigus after enalapril intake. Dermatology (2003) 207:336-7. doi: 10.1159/000073106

12. Giomi B, Cardinali C, Pestelli E, Caproni M, Fabbri P. Pemphigus foliaceus developing on pre-existing psoriasis: a supposed pathogenetic linkage. Acta Derm Venereol. (2004) 84:82-3. doi: 10.1080/00015550310020567

13. Sanchez-Palacios C, Chan LS. Development of pemphigus herpetiformis in a patient with psoriasis receiving UV-light treatment. J Cutan Pathol. (2004) 31:346-9. doi: 10.1111/j.0303-6987.2004.0188.x

14. Hasse-Cieslinska M, Dmochowski M, Bowszyc-Dmochowska M, Silny W, Danczak-Pazdrowska A. [A case of sporadic pemphigus foliaceus in teenage girl with psoriasis vulgaris]. Pol Merkur Lekarski (2005) 18:568-70.

15. Masmoudi A, Hadj Taieb H, Ben Ayed M, Abida O, Makni H, Turki $\mathrm{H}$, et al. [Tunisian erythematosus pemphigus associated with psoriasis in two sisters]. Ann Dermatol Venereol. (2006) 133:184-5. doi: 10.1016/S0151-9638(06)77553-6

16. Caldarola G, Carbone A, De Simone C, Pellicano R. Development of pemphigus vulgaris in a patient with psoriasis treated with cyclosporine. $J$ Am Acad Dermatol. (2010) 63:356-7. doi: 10.1016/j.jaad.2009.05.032

17. Rallis E, Stavropoulos P, Christofidou E, Rigopoulos D, KoumantakiMathioudaki E. Pemphigus vulgaris with plaque-type psoriasis successfully treated with cyclosporine monotherapy. Am J Clin Dermatol. (2011) 12:2834. doi: 10.2165/11586680-000000000-00000

18. Rosmaninho A, Oliveira A, Sanches M, Velho G, Amorim I, Selores M. IgA pemphigus and pustular psoriasis: a possible relation. Eur J Dermatol. (2011) 21:100-1. doi: 10.1684/ejd.2011.1159

19. Grekin SJ, Fox MC, Gudjonsson JE, Fullen DR. Psoriasiform pemphigus foliaceus: a report of two cases. J Cutan Pathol. (2012) 39:549-53. doi: 10.1111/j.1600-0560.2012.01866.x

20. Kato K, Hanafusa T, Igawa K, Tatsumi M, Takahashi Y, Yamanaka T, et al. A rare case of annular pustular psoriasis associated with pemphigus foliaceus. Ann Dermatol. (2014) 26:260-1. doi: 10.5021/ad.2014.26.2.260

21. Kurtzman DJ, Christopher M, Lian F, Sligh JE. A blistering response: concurrent psoriasis and pemphigus foliaceus. Am J Med. (2015) 128:24-6. doi: 10.1016/j.amjmed.2014.09.003

22. Claus S, Ziemer M, Simon JC, Treudler R. Coincidence of annular pustular psoriasis, pemphigus foliaceus, and leukocytoclastic vasculitis associated with chronic cholecystitis. J Dtsch Dermatol Ges. (2016) 14:830-1. doi: $10.1111 /$ ddg. 12619

23. Sanz-Bueno J, Gallo E, Caro-Gutierrez D, Sanchez-Gilo A, Gutierrez Pascual M, Rojas-Scheffer L, et al. Penfigo foliaceo agravado por farmacos en un paciente con psoriasis, con buena respuesta a adalimumab. Dermatol Online J. 23:13030/qt8tr4j1f2.

24. Sousa VB, Santana C, Pereira DDN, Gripp AC. Pemphigus foliaceus with pustular presentation in a patient with psoriasis. An Bras Dermatol. (2017) 92:115-7. doi: 10.1590/abd1806-4841.20175709

25. Fujimoto N, Matsuo S, Satoh T. Psoriasis vulgaris in a patient with pemphigus vulgaris on corticosteroid therapy. J Dtsch Dermatol Ges. (2018) 16:606-8. doi: 10.1111/ddg.13505

26. Person JR, Rogers RS III. Bullous pemphigoid and psoriasis: does subclinical bullous pemphigoid exist? Br. J. Dermatol. (1976) 95, 535-540.

27. Ahmed AR, Winkler NW. Psoriasis and bullous pemphigoid. Arch Dermatol. (1977) 113:845. doi: 10.1001/archderm.1977.01640060141023
28. Robledo, A., Pais, T., Nine, C., Fonseca T. [Bullous pemphigoid and psoriasis]. Actas Dermosifiliogr. (1977) 68:409-416.

29. Koerber WAJr, Price NM, Watson W. Coexistent psoriasis and bullous pemphigoid: a report of six cases. Arch Dermatol. (1978) 114:1643-6. doi: 10.1001/archderm.1978.01640230017005

30. Stuttgen G, Bockendahl H, Remy W, Lewicki D. [Psoriasis and bullous dermatoses]. Hautarzt (1978) 29:134-40.

31. Abel EA, Bennett A. Bullous pemphigoid. Occurrence in psoriasis treated with psoralens plus long-wave ultraviolet radiation. Arch Dermatol. (1979) 115:988-9. doi: 10.1001/archderm.1979.04010080052026

32. Stuttgen G, Kentsch V. Psoriasis and pemphigoid positive correlation. Acta Derm Venereol Suppl. (1979) 87:99-101.

33. Olmos L, De Diego V. [Psoriasis and pemphigoid (author's transl)]. Dermatologica (1981) 163:105-12. doi: 10.1159/000250146

34. Albergo RP, Gilgor RS. Delayed onset of bullous pemphigoid after PUVA and sunlight treatment of psoriasis. Cutis (1982) 30:621-4.

35. Brun P, Baran R. [Bullous pemphigoid induced by photochemotherapy of psoriasis. Apropos of 2 cases, with a review of the literature]. Ann. Dermatol. Venereol. (1982) 109:461-468.

36. Wallach D, Cottenot F. Erythrodermic bullous pemphigoid or erythrodermic psoriasis and bullous pemphigoid? J Am Acad Dermatol. (1982) 7:800.

37. Mashkilleison AL, Golousenko I, Reznikova MM. [Bullous pemphigoid associated with psoriasis]. Vestn Dermatol Venerol. (1983) $37-8$.

38. Weltfriend S, David M, Feuerman EJ. [Bullous pemphigoid in a patient with psoriasis]. Harefuah (1983) 105:218-9.

39. Barba A, Leoni A, Peroni A. [Psoriasis and pemphigoid]. G Ital Dermatol Venereol. (1985) 120:75-7.

40. Grattan CE. Evidence of an association between bullous pemphigoid and psoriasis. $\mathrm{Br} J$ Dermatol. (1985) 113:281-3. doi: 10.1111/j.1365-2133.1985.tb02079.x

41. Mozzanica N, Tadini GL, Pigatto P, Altomare GF. [Psoriasis and bullous pemphigoid. Presentation of 2 cases]. G. Ital. Dermatol. Venereol. (1985) 120:189-92.

42. Bork K. [Psoriasis and bullous pemphigoid]. Hautarzt (1987) 38:348-51.

43. Wollina $U$, Roth $H$. [Psoriasis vulgaris partim inversa and bullous pemphigoid. Case report and short review of the literature] Dermatol Monatsschr. (1987) 173:29-32.

44. Rotoli M, Rossi GF, Bono R, Rusciani L. [Association of psoriasis and bullous pemphigoid. Clinical case] G Ital Dermatol Venereol. (1988) 123:161-2.

45. Di Silverio A, Vignini M, Gabba P, Bellosta M, Brandozzi G. [Psoriasispemphigoid association. Description of a case] G Ital Dermatol Venereol. (1989) 124:359-61.

46. Nicoletti A, Riva MI, Crippa D, Sala GP, Albanese G, Beneggi M. [Psoriasis and bullous pemphigoid. Description of 3 clinical cases]. G. Ital. Dermatol. Venereol. (1989) 124:277-9.

47. Weber PJ, Salazar JE. Bullous eruption in a psoriatic patient. Bullous pemphigoid and psoriasis. Arch Dermatol. (1989) 125:691-2.

48. Bianchi L, Gatti S, Nini G. Bullous pemphigoid and severe erythrodermic psoriasis: combined low-dose treatment with cyclosporine and systemic steroids. J Am Acad Dermatol. (1992) 27:278. doi: 10.1016/S0190-9622(08)80749-9

49. Chen KR, Shimizu S, Miyakawa S, Ishiko A, Shimizu H, Hashimoto T. Coexistence of psoriasis and an unusual IgG-mediated subepidermal bullous dermatosis: identification of a novel 200-kDa lower lamina lucida target antigen. $\mathrm{Br} J$ Dermatol. (1996) 134:340-6. doi: 10.1111/j.1365-2133.1996.tb07625.x

50. George PM. Bullous pemphigoid possibly induced by psoralen plus ultraviolet A therapy. Photodermatol Photoimmunol Photomed. (1996) 11:185-7. doi: 10.1111/j.1600-0781.1995.tb00166.x

51. Kirtschig G, Chow ET, Venning VA, Wojnarowska FT. Acquired subepidermal bullous diseases associated with psoriasis: a clinical, immunopathological and immunogenetic study. $\mathrm{Br} J$ Dermatol. (1996) 135:738-45. doi: 10.1111/j.1365-2133.1996.tb0 3883.x

52. Perl S, Rappersberger K, Fodinger D, Anegg B, Honigsmann H, Ortel B. Bullous pemphigoid induced by PUVA therapy. Dermatology (1996) 193:245-7. doi: 10.1159/000246255 
53. Rotstein H. Psoriasis: changing clinical patterns. Australas J Dermatol. (1996) 37 (Suppl. 1):S27-9. doi: 10.1111/j.1440-0960.1996.tb01075.x

54. Saeki H, Hayashi N, Komine M, Soma Y, Shimada S, Watanabe K, et al. A case of generalized pustular psoriasis followed by bullous disease: an atypical case of bullous pemphigoid or a novel bullous disease? Br J Dermatol. (1996) 134:152-5.

55. Primka EJ III, Camisa C. Psoriasis and bullous pemphigoid treated with azathioprine. J. Am. Acad. Dermatol. (1998) 39:121-123. doi: 10.1016/S0190-9622(98)70414-1

56. Roeder C, Driesch PV. Psoriatic erythroderma and bullous pemphigoid treated successfully with acitretin and azathioprine. Eur J Dermatol. (1999) 9:537-9.

57. Kawahara Y, Zillikens D, Yancey KB, Marinkovich MP, Nie Z, Hashimoto $\mathrm{T}$, et al. Subepidermal blistering disease with autoantibodies against a novel dermal 200-kDa antigen. J Dermatol Sci. (2000) 23:93-102. doi: 10.1016/S0923-1811(99)00093-6

58. Kobayashi TT, Elston DM, Libow LF, David-Bajar K. A case of bullous pemphigoid limited to psoriatic plaques. Cutis (2002) 70:283-7.

59. Pasic A, Ljubojevic S, Lipozencic J, Marinovic B, Loncaric D. Coexistence of psoriasis vulgaris, bullous pemphigoid and vitiligo: a case report. J Eur Acad Dermatol Venereol. (2002) 16:426-7. doi: 10.1046/j.1468-3083.2002.00570_12.x

60. Burnett PE. Bullous pemphigoid and psoriasis vulgaris. Dermatol Online J. (2003) 9:19.

61. Paul J. Bullous pemphigoid in a patient with psoriasis and possible drug reaction: a case report. Conn Med. (2004) 68:611-5.

62. Yasuda H, Tomita Y, Shibaki A, Hashimoto T. Two cases of subepidermal blistering disease with anti-p200 or $180-\mathrm{kD}$ bullous pemphigoid antigen associated with psoriasis. Dermatology (2004) 209:149-55. doi: 10.1159/000079602

63. Bourdon-Lanoy E, Roujeau JC, Joly P, Guillaume JC, Bernard P, Prost $\mathrm{C}$, et al. [Bullous pemphigoid in young patients: a retrospective study of 74 cases]. Ann Dermatol Venereol. (2005) 132:115-22. doi: 10.1016/S0151-9638(05)79220-6

64. Washio H, Hara H, Suzuki H, Yoshida M, Hashimoto T. Bullous pemphigoid on psoriasis lesions after UVA radiation. Acta Derm Venereol. (2005) 85:5613. doi: 10.1080/00015550510035677

65. Arregui MA, Soloeta R, Gonzalez R, Garcia I, Trebol I, Tamayo C. [Bullous pemphigoid related to PUVA therapy: two further cases]. Actas Dermosifiliogr. (2006) 97:444-7. doi: 10.1016/S0001-7310(06)73437-8

66. Barnadas MA, Gilaberte M, Pujol R, Agusti M, Gelpi C, Alomar A. Bullous pemphigoid in a patient with psoriasis during the course of PUVA therapy: study by ELISA test. Int J Dermatol. (2006) 45:1089-92. doi: 10.1111/j.1365-4632.2004.02517.x

67. Lazarczyk M, Wozniak K, Ishii N, Gorkiewicz-Petkov A, Hashimoto T, Schwarz R, et al. Coexistence of psoriasis and pemphigoid-only a coincidence? Int J Mol Med. (2006) 18:619-23. doi :10.3892/ijmm.18.4.619

68. Wilczek A, Sticherling M. Concomitant psoriasis and bullous pemphigoid: coincidence or pathogenic relationship? Int J Dermatol. (2006) 45:1353-7. doi: 10.1111/j.1365-4632.2006.02861.x

69. Yamauchi PS, Lowe NJ, Gindi V. Treatment of coexisting bullous pemphigoid and psoriasis with the tumor necrosis factor antagonist etanercept. J Am Acad Dermatol. (2006) 54:S121-2. doi: 10.1016/j.jaad.2005.10.055

70. Sugita K, Kabashima K, Nishio D, Hashimoto T, Tokura Y. Th2 cell fluctuation in association with reciprocal occurrence of bullous pemphigoid and psoriasis vulgaris. J Eur Acad Dermatol Venereol. (2007) 21:569-70. doi: 10.1111/j.1468-3083.2006.01966.x

71. Miyakura T, Yamamoto T, Tashiro A, Okubo Y, Oyama B, Ishii N, et al. Antip200 pemphigoid associated with annular pustular psoriasis. Eur J Dermatol. (2008) 18:481-2. doi: 10.1684/ejd.2008.0465

72. Rallis E, Anyfantakis V. Coexistent psoriasis and bullous pemphigoid responding to mycophenolate mofetil monotherapy. Skinmed (2008) 7:1012. doi: 10.1111/j.1751-7125.2008.07318.x

73. Saraceno R, Citarella L, Spallone G, Chimenti S. A biological approach in a patient with psoriasis and bullous pemphigoid associated with losartan therapy. Clin Exp Dermatol. (2008) 33:154-5. doi: $10.1111 /$ j.1365-2230.2007.02603.x
74. Inokuma D, Kodama K, Natsuga K, Kasai M, Abe M, Nishie W, et al. Autoantibodies against type XVII collagen C-terminal domain in a patient with bullous pemphigoid associated with psoriasis vulgaris. $\mathrm{Br} J$ Dermatol. (2009) 160:451-4. doi: 10.1111/j.1365-2133.2008.08961.x

75. Monnier-Murina K, Du Thanh A, Merlet-Albran S, Guillot B, Dereure O. Bullous pemphigoid occurring during efalizumab treatment for psoriasis: a paradoxical auto-immune reaction? Dermatology (2009) 219:89-90. doi: $10.1159 / 000207792$

76. Stausbol-Gron B, Deleuran M, Sommer Hansen E, Kragballe K. Development of bullous pemphigoid during treatment of psoriasis with adalimumab. Clin Exp Dermatol. (2009) 34:e285-6. doi: 10.1111/j.1365-2230.2008.03204.x

77. Yasukawa S, Dainichi T, Kokuba H, Moroi Y, Urabe K, Hashimoto T, et al. Bullous pemphigoid followed by pustular psoriasis showing Th1, Th2, Treg and Th17 immunological changes. Eur J Dermatol. (2009) 19:69-71. doi: 10.1684/ejd.2008.0572

78. Cusano F, Iannazzone SS, Riccio G, Piccirillo F. Coexisting bullous pemphigoid and psoriasis successfully treated with etanercept. Eur J Dermatol. (2010) 20:520. doi: 10.1684/ejd.2010.0970

79. Kluk J, Goulding JM, Bhat J, Finch TM. Drug-induced bullous pemphigoid: cases triggered by intravenous iodine and etanercept. Clin Exp Dermatol. (2011) 36:871-3. doi: 10.1111/j.1365-2230.2011.04102.x

80. Kwon HH, Kwon IH, Chung JH, Youn JI. Pemphigus foliaceus associated with psoriasis during the course of narrow-band UVB therapy: a simple coincidence? Ann Dermatol. (2011) 23:S281-4. doi: 10.5021/ad.2011.23.S3.S281

81. Rao R, Gupta A, Yunis F, Handettu S, Chandrashekar B. Coexistence of psoriasis with bullous pemphigoid. Indian Dermatol Online J. (2012) 3:119_ 21. doi: 10.4103/2229-5178.96707

82. Gunay U, Gunduz K, Ermertcan AT, Kandiloglu AR. Coexistence of psoriasis and bullous pemphigoid: remission with low-dose methotrexate. Cutan Ocul Toxicol. (2013) 32:168-9. doi: 10.3109/15569527.2012.667030

83. Majima Y, Yagi H, Tateishi C, Groth S, Schmidt E, Zillikens D, et al. A successful treatment with ustekinumab in a case of antilaminin-gammal pemphigoid associated with psoriasis. Br J Dermatol. (2013) 168:1367-9. doi: 10.1111/bjd.12163

84. Ohata C, Fukuda S, Ishii N, Koga H, Hamada T, Furumura M, et al. Refractory anti-laminin gammal pemphigoid with psoriasis vulgaris successfully treated by double-filtration plasmapheresis. Eur J Dermatol. (2013) 23:715-6. doi: 10.1684/ejd.2013.2138

85. Ansai S, Hashizume S, Kawana S, Tateishi C, Koga H, Hashimoto T. Case of anti-laminin gamma-1 pemphigoid with antibody against C-terminal domain of BP180 in a patient with psoriasis vulgaris. J Dermatol. (2014) 41:1031-3. doi: 10.1111/1346-8138.12625

86. Igarashi M, Tsunemi Y, Koga H, Hashimoto T, Tateishi C, Tsuruta D, et al. Anti-laminin gammal pemphigoid associated with pustular psoriasis. Eur J Dermatol. (2014) 24:629-30. doi: 10.1684/ejd.2014.2419

87. Jankowski M, Czajkowski R, Scibior K, Schwartz RA. Coexistence of psoriasis vulgaris and vitiligo with bullous pemphigoid: a case report. Int J Dermatol. (2014) 53:e359-61. doi: 10.1111/ijd.12349

88. Li Z, Jin P, Feng S, Wang B. Treatment of coexisting bullous pemphigoid and psoriasis with triptergium wilfordii. Chin Med J. (2014) 127:3037.

89. Marek-Jozefowicz L, Scibior K, Czajkowski R. PUVA induced bullous pemphigoid in a patient with psoriasis. Acta Dermatovenerol Croat. (2014) 22:301-4.

90. Si X, Ge L, Xin H, Cao W, Sun X, Li W. Erythrodermic psoriasis with bullous pemphigoid: combination treatment with methotrexate and compound glycyrrhizin. Diagn Pathol. (2014) 9:102. doi: 10.1186/1746-1596-9-102

91. Stoica LE, Patrascu V, Dascalu RC, Ciurea ME. Bullous pemphigoid associated with psoriasis, breast cancer and Parkinson's disease. Curr Health Sci J. (2014) 40:62-6. doi: 10.12865/CHSJ.40.01.12

92. Wang TS, Tsai TF. Remission of bullous pemphigoid after rituximab treatment in a psoriasis patient on regular low-dose methotrexate. Acta Derm Venereol. (2014) 94:108-9. doi: 10.2340/00015555-1619

93. Akasaka E, Nakano H, Korekawa A, Fukui T, Kaneko T, Koga H, et al. Antilaminin gammal pemphigoid associated with ulcerative colitis and psoriasis vulgaris showing autoantibodies to laminin gamma1, type XVII collagen and laminin-332. Eur J Dermatol. (2015) 25:198-9. doi: 10.1684/ejd.2014.2499 
94. Garrido Colmenero C, Arias Santiago S, Blasco Morente G, Perez Lopez I, Aneiros Fernandez J. Photoletter to the editor: Psoriatic erythroderma associated with bullous pemphigoid: clinical appearance and histopathology. J Dermatol Case Rep. (2015) 9:23-4. doi: 10.3315/jdcr.2015.1194

95. Iino Y, Kano T, Adachi F, Suzuki M, Nishikawa R, Ishii N, et al. A case of bullous pemphigoid associated with psoriasis vulgaris showing Hailey-Hailey disease-like histopathological changes in regenerated epidermis without genomic mutation in ATP2C1 or ATP2A2 gene. J Eur Acad Dermatol Venereol. (2015) 29:1646-8. doi: 10.1111/jdv.12521

96. Imanishi A, Tateishi C, Imanishi H, Sowa-Osako J, Koga H, Tsuruta $\mathrm{D}$, et al. Pemphigoid with antibodies to laminin gamma1, BP180 and BP230, associated with psoriasis vulgaris: successful disease control with cyclosporin. J Dermatol. (2015) 42:394-7. doi: 10.1111/1346-8138.12798

97. Ishida S, Takahashi K, Kanaoka M, Okawa T, Tateishi C, Yasukochi A, et al. Case of subepidermal autoimmune bullous disease with psoriasis vulgaris reacting to both BP180 C-terminal domain and laminin gamma-1. J Dermatol. (2015) 42:391-3. doi: 10.1111/1346-8138.12801

98. Iskandarli M, Gerceker Turk B, Yaman B, Ozturk G. Pemphigoid diseases as a sign of active psoriasis: a case report and brief review. Dermatology (2015) 231:319-21. doi: 10.1159/000435912

99. Nakayama C, Fujita Y, Watanabe M, Shimizu H. Development of bullous pemphigoid during treatment of psoriatic onychopachydermo periostitis with ustekinumab. J Dermatol. (2015a) 42:996-8. doi: 10.1111/1346-8138.12943

100. Nakayama C, Iwata H, Haga N, Hamade Y, Mizuno O, Nishie W, et al. The different intensity of autoantibody deposits in bullous pemphigoid associated with psoriasis vulgaris. Eur J Dermatol. (2015b) 25:70-1. doi: 10.1684/ejd.2014.2444

101. Okahashi K, Oiso N, Ishii N, Uchida S, Matsuda H, Hashimoto T, et al. Bullous pemphigoid associated with psoriasis: a possible example of an inverse intramolecular epitope-spreading phenomenon. J Dermatol. (2015) 42:758-9. doi: 10.1111/1346-8138.12891

102. Caca-Biljanovska N, Arsovska-Bezhoska I, V'lckova-Laskoska M. PUVAinduced bullous pemphigoid in psoriasis. Acta Dermatovenerol. Croat. (2016) 24:214-7.

103. Commin MH, Schmidt E, Duvert-Lehembre S, Lasek A, Morice C, Estival $\mathrm{JL}$, et al. Clinical and immunological features and outcome of anti-p200 pemphigoid. Br J Dermatol. (2016) 175:776-81. doi: 10.1111/bjd.14629

104. Fujimura Y, Natsuga K, Hamade Y, Nomura Y, Kaku Y, Muramatsu $\mathrm{R}$, et al. Anti-laminin-gamma 1 pemphigoid with generalized pustular psoriasis and psoriasis vulgaris. Acta Derm Venereol. (2016) 96:120-1. doi: 10.2340/00015555-2168

105. Lesniewska A, Kalinska-Bienias A, Kowalewski C, Schwartz R, Wozniak $\mathrm{K}$. Development of bullous pemphigoid in a patient with psoriasis and metabolic syndrome. Cutis (2016) 98:E19-23.

106. Maki N, Demitsu T, Umemoto N, Nagashima K, Nakamura T, Kakurai M, et al. Possible paraneoplastic syndrome case of bullous pemphigoid with immunoglobulin G anti-BP180 C-terminal domain antibodies associated with psoriasis and primary macroglobulinemia. J Dermatol. (2016) 43:571-4. doi: 10.1111/1346-8138.13170

107. Ho PH, Tsai TF. Development of bullous pemphigoid during secukinumab treatment for psoriasis. J Dermatol. (2017) 44:e220-1. doi: 10.1111/1346-8138.13909

108. Loget J, Plee J, Antonicelli F, Bernard P. A successful treatment with ustekinumab in a case of relapsing bullous pemphigoid associated with psoriasis. J Eur Acad Dermatol Venereol. (2017) 31:e228-30. doi: $10.1111 /$ jdv.14002

109. Ohashi M, Takagi H, Mizutani Y, Seishima M, Koga H, Hashimoto T. Bullous pemphigoid with IgG autoantibodies to the alpha3 subunit of laminin 332 associated with psoriasis vulgaris. Eur J Dermatol. (2017) 27:306-7. doi: 10.1684/ejd.2017.2980

110. Endo Y, Tamura A, Ishikawa O, Miyachi Y, Hashimoto T. Psoriasis vulgaris coexistent with epidermolysis bullosa acquisita. Br J Dermatol. (1997) 137:783-6. doi: 10.1111/j.1365-2133.1997.tb01119.x

111. Morris SD, Mallipeddi R, Oyama N, Gratian MJ, Harman KE, Bhogal BS, et al. Psoriasis bullosa acquisita. Clin Exp Dermatol. (2002) 27:665-9. doi: 10.1046/j.1365-2230.2002.01100.x
112. Hoshina D, Sawamura D, Nomura T, Tanimura S, Abe M, Onozuka T, et al Epidermolysis bullosa acquisita associated with psoriasis vulgaris. Clin Exp Dermatol. (2007) 32:516-8. doi: 10.1111/j.1365-2230.2007.02430.x

113. Kabashima R, Hino R, Bito T, Kabashima K, Nakamura M, Bungo O, et al. Epidermolysis bullosa acquisita associated with psoriasis. Acta Derm Venereol. (2010) 90:314-6. doi: 10.2340/00015555-0832

114. Min L, Kensuke M, Takashi H, Naoyuki H. Epidermolysis bullosa acquisita in a patient with psoriasis vulgaris. Eur J Dermatol. (2015) 25:499-500. doi: $10.1684 /$ ejd.2015.2623

115. Moon SY, Eun DH, Jung HJ, Kim JY, Park TI, Lee WJ, et al. Coexistence of psoriasis and epidermolysis bullosa acquisita: evaluation of the integrity of the basement membrane. J Cutan Pathol. (2017) 44:602-3. doi: $10.1111 /$ cup. 12940

116. Gubinelli E, Angelo C, Pacifico V. A case of dystrophic epidermolysis bullosa improved with etanercept for concomitant psoriatic arthritis. Am J Clin Dermatol (2010) 11 (Suppl. 1):53-4. doi: 10.2165/1153427-S0-000000000-00000

117. Heaphy MR, Winkelmann RK. Coexistence of benign familial pemphigus and psoriasis vulgaris. Arch Dermatol. (1976) 112:1571-4. doi: 10.1001/archderm.1976.01630350047013

118. Boxley JD, Byrne JP, Summerly R. Bi-directional isomorphism: coexistence of psoriasis vulgaris and familial benign chronic pemphigus. Arch Dermatol. (1977) 113:846-7. doi: 10.1001/archderm.1977.01640060142025

119. Kochergin NG, Shkrebets SV. [Combination of psoriasis and Hailey-Hailey disease]. Vestn Dermatol Venerol. (1987) 68-70.

120. Mallen JK. Psoriasis, chronic benign familial pemphigus, and dysplastic naevus syndrome in a family. Australas J Dermatol. (1992) 33:55. doi: 10.1111/j.1440-0960.1992.tb00059.x

121. Hayakawa K, Shiohara T. Coexistence of psoriasis and familial benign chronic pemphigus: efficacy of ultraviolet B treatment. Br J Dermatol. (1999) 140:374-5. doi: 10.1046/j.1365-2133.1999.02690.x

122. Santos-Juanes J, Coto-Segura P, Saavedra J, Laviano S, Galache C. Development of familial benign chronic pemphigus in a patient undergoing treatment with efalizumab for psoriasis. J Eur Acad Dermatol Venereol. (2009) 23:605-6. doi: 10.1111/j.1468-3083.2008.02979.x

123. Chao SC, Lee JY, Wu MC, Hsu MM. A novel splice mutation in the ATP2C1 gene in a woman with concomitant psoriasis vulgaris and disseminated Hailey-Hailey disease. Int J Dermatol. (2012) 51:947-51. doi: 10.1111/j.1365-4632.2010.04800.x

124. Ohata C, Ishii N, Koga H, Fukuda S, Tateishi C, Tsuruta D, et al. Coexistence of autoimmune bullous diseases (AIBDs) and psoriasis: a series of 145 cases. J Am Acad Dermatol. (2015) 73:50-5. doi: 10.1016/j.jaad.2015.03.016

125. Tsai TF, Wang TS, Hung ST, Tsai PI, Schenkel B, Zhang M, et al. Epidemiology and comorbidities of psoriasis patients in a national database in Taiwan. J Dermatol Sci. (2011) 63:40-6. doi: 10.1016/j.jdermsci.2011.03.002

126. Kridin K, Zelber-Sagi S, Comaneshter D, Cohen AD. Association between pemphigus and psoriasis: a population-based large-scale study. J Am Acad Dermatol. (2017) 77:1174-5. doi: 10.1016/j.jaad.2017.07.007

127. Chen YJ, Wu CY, Lin MW, Chen TJ, Liao KK, Chen YC, et al. Comorbidity profiles among patients with bullous pemphigoid: a nationwide population-based study. Br J Dermatol. (2011) 165:593-9. doi: 10.1111/j.1365-2133.2011.10386.x

128. Kridin K, Bergman R. Association between bullous pemphigoid and psoriasis: a case-control study. J Am Acad Dermatol. (2017) 77:370-2. doi: 10.1016/j.jaad.2017.02.057

129. Dainichi T, Koga H, Tsuji T, Ishii N, Ohyama B, Ueda A, et al. From antip200 pemphigoid to anti-laminin gammal pemphigoid. J Dermatol. (2010) 37:231-8. doi: 10.1111/j.1346-8138.2009.00793.x

130. Perera GK, Di Meglio P, Nestle FO. Psoriasis. Annu Rev Pathol. (2012) 7:385-422. doi: 10.1146/annurev-pathol-011811-1 32448

131. Hammers CM, Stanley JR. Mechanisms of Disease: Pemphigus and Bullous Pemphigoid. Annu Rev Pathol. (2016) 11:175-97. doi: 10.1146/annurev-pathol-012615-044313

132. Schmidt E, Zillikens D. Pemphigoid diseases. Lancet (2013) 381:320-32. doi: 10.1016/S0140-6736(12)61140-4 
133. Ray-Jones H, Eyre S, Barton A, Warren RB. One SNP at a Time: Moving beyond GWAS in Psoriasis. J Invest Dermatol. (2016) 136:567-73. doi: $10.1016 /$ j.jid.2015.11.025

134. Tian S, Krueger JG, Li K, Jabbari A, Brodmerkel C, Lowes MA, et al. Meta-analysis derived (MAD) transcriptome of psoriasis defines the "core" pathogenesis of disease. PLoS ONE (2012) 7:e44274. doi: 10.1371/journal.pone.0044274

135. Chang YT, Liu HN, Yu CW, Lin MW, Huang CH, Chen CC, et al. Cytokine gene polymorphisms in bullous pemphigoid in a Chinese population. $\mathrm{Br} \mathrm{J}$ Dermatol. (2006) 154:79-84. doi: 10.1111/j.1365-2133.2005.06938.x

136. Weisenseel P, Martin S, Partscht K, Messer G, Prinz JC. Relevance of the low-affinity type of the Fcgamma-receptor IIIa-polymorphism in bullous pemphigoid. Arch Dermatol Res. (2007) 299:163-4. doi: 10.1007/s00403-007-0755-8

137. Hirose M, Schilf P, Benoit S, Eming R, Glaser R, Homey B, et al. Polymorphisms in the mitochondrially encoded ATP synthase 8 gene are associated with susceptibility to bullous pemphigoid in the German population. Exp Dermatol. (2015) 24:715-7. doi: 10.1111/exd.12732

138. Rychlik-Sych M, Baranska M, Wojtczak A, Skretkowicz J, Zebrowska A, Waszczykowska E. The impact of the CYP2D6 gene polymorphism on the risk of pemphigoid. Int J Dermatol. (2015) 54:1396-401. doi: 10.1111/ijd.12967

139. Malheiros D, Petzl-Erler ML. Individual and epistatic effects of genetic polymorphisms of B-cell co-stimulatory molecules on susceptibility to pemphigus foliaceus. Genes Immun. (2009) 10:547-58. doi: 10.1038/gene.2009.36

140. Tanasilovic S, Popadic S, Medenica L, Popadic D. Pemphigus vulgaris and pemphigus foliaceus determined by CD86 and CTLA4 polymorphisms. Clin Dermatol. (2017) 35:236-41. doi: 10.1016/j.clindermatol.2016.05.021

141. Salviano-Silva A, Petzl-Erler ML, Boldt ABW. CD59 polymorphisms are associated with gene expression and different sexual susceptibility to pemphigus foliaceus. Autoimmunity (2017) 50:377-85. doi: 10.1080/08916934.2017.1329830

142. Hebert HL, Bowes J, Smith RL, Mchugh NJ, Barker J, Griffiths CEM, et al. Polymorphisms in IL-1B distinguish between psoriasis of early and late onset. J Invest Dermatol. (2014) 134:1459-62. doi: 10.1038/jid.2013.485

143. Sadik CD, Bischof J, Van Beek N, Dieterich A, Benoit S, Sardy M, et al. Genomewide association study identifies GALC as susceptibility gene for mucous membrane pemphigoid. Exp Dermatol. (2017) 26:1214-20. doi: 10.1111/exd.13464

144. Malheiros D, Panepucci RA, Roselino AM, Araujo AG, Zago MA, PetzlErler ML. Genome-wide gene expression profiling reveals unsuspected molecular alterations in pemphigus foliaceus. Immunology (2014) 143:38195. doi: 10.1111/imm.12315

145. Ludwig RJ, Vanhoorelbeke K, Leypoldt F, Kaya Z, Bieber K, Mclachlan SM, et al. Mechanisms of autoantibody-induced pathology. Front Immunol. (2017) 8:603. doi: 10.3389/fimmu.2017.00603

146. Ono S, Egawa G, Kitoh A, Dainichi T, Otsuka A, Nakajima S, et al. Local inflammation exacerbates cutaneous manifestations in a murine autoimmune pemphigus model. J Allergy Clin Immunol. (2017) 139:20268.e2025. doi: 10.1016/j.jaci.2016.12.959

147. Arakawa M, Dainichi T, Ishii N, Hamada T, Karashima T, Nakama T, et al. Lesional Th17 cells and regulatory $\mathrm{T}$ cells in bullous pemphigoid. Exp Dermatol. (2011) 20:1022-4. doi: 10.1111/j.1600-0625.2011.01378.x
148. Takahashi H, Kuwana M, Amagai M. A single helper $\mathrm{T}$ cell clone is sufficient to commit polyclonal naive B cells to produce pathogenic IgG in experimental pemphigus vulgaris. J Immunol. (2009) 182:1740-5. doi: 10.4049/jimmunol.182.3.1740

149. Nishimoto S, Kotani H, Tsuruta S, Shimizu N, Ito M, Shichita T, et al. Th17 cells carrying TCR recognizing epidermal autoantigen induce psoriasis-like skin inflammation. J Immunol. (2013) 191:3065-72. doi: 10.4049/jimmunol.1300348

150. Schmidt T, Solimani F, Pollmann R, Stein R, Schmidt A, Stulberg I, et al. TH1/TH17 cell recognition of desmoglein 3 and bullous pemphigoid antigen 180 in patients with lichen planus. J. Allergy Clin. Immunol. (2018) doi: 10.1016/j.jaci.2018.02.044. [Epub ahead of print].

151. Gal B, Dulic S, Kiss M, Groma G, Kovacs L, Kemeny L, et al. Increased circulating anti-alpha6-integrin autoantibodies in psoriasis and psoriatic arthritis but not in rheumatoid arthritis. J Dermatol. (2017) 44:370-4. doi: $10.1111 / 1346-8138.13667$

152. Nishie W. Update on the pathogenesis of bullous pemphigoid: an autoantibody-mediated blistering disease targeting collagen XVII. J Dermatol Sci. (2014) 73:179-86. doi: 10.1016/j.jdermsci.2013.12.001

153. Mezentsev A, Nikolaev A, Bruskin S. Matrix metalloproteinases and their role in psoriasis. Gene (2014) 540:1-10. doi: 10.1016/j.gene.2014. 01.068

154. Dainichi T, Kurono S, Ohyama B, Ishii N, Sanzen N, Hayashi M, et al. Antilaminin gamma-1 pemphigoid. Proc Natl Acad Sci USA. (2009) 106:2800-5. doi: $10.1073 /$ pnas. 0809230106

155. Chan LS, Ahmed AR, Anhalt GJ, Bernauer W, Cooper KD, Elder $\mathrm{MJ}$, et al. The first international consensus on mucous membrane pemphigoid: definition, diagnostic criteria, pathogenic factors, medical treatment, and prognostic indicators. Arch Dermatol. (2002) 138:370-9. doi: 10.1001/archderm.138.3.370

156. Mcfadden JP, Powles A, Kimber I, Fry L. Psoriasis and basement-membrane laminin. Br J Dermatol. (2013) 169:718-9. doi: 10.1111/bjd.12400

157. Wu K, Higashi N, Hansen ER, Lund M, Bang K, Thestrup-Pedersen K. Telomerase activity is increased and telomere length shortened in $\mathrm{T}$ cells from blood of patients with atopic dermatitis and psoriasis. J Immunol. (2000) 165:4742-7. doi: 10.4049/jimmunol.165.8.4742

158. Watanabe M, Natsuga K, Nishie W, Kobayashi Y, Donati G, Suzuki S, et al. Type XVII collagen coordinates proliferation in the interfollicular epidermis. Elife (2017) 6:e26635. doi: 10.7554/eLife.26635

159. Matsumura H, Mohri $\mathrm{Y}$, Binh NT, Morinaga $\mathrm{H}$, Fukuda $\mathrm{M}$, Ito $\mathrm{M}$, et al. Hair follicle aging is driven by transepidermal elimination of stem cells via COL17A1 proteolysis. Science (2016) 351:aad4395. doi: $10.1126 /$ science.aad 4395

Conflict of Interest Statement: The authors declare that the research was conducted in the absence of any commercial or financial relationships that could be construed as a potential conflict of interest.

Copyright $(2) 2018$ Dainichi and Kabashima. This is an open-access article distributed under the terms of the Creative Commons Attribution License (CC BY). The use, distribution or reproduction in other forums is permitted, provided the original author(s) and the copyright owner(s) are credited and that the original publication in this journal is cited, in accordance with accepted academic practice. No use, distribution or reproduction is permitted which does not comply with these terms. 